\title{
SAFO EM SODOMA: \\ A ESCRITA FEMININA DE JUDITH TEIXEIRA \\ EM TEMPOS DE ORPHEU
}

\author{
Jorge Valentim ${ }^{1}$ \\ (Universidade Federal de São Carlos)
}

\section{RESUMO}

O presente ensaio tem como objetivo uma proposta de leitura da obra poética de Judith Teixeira, tendo como viés norteador a sua escrita feminina sob o signo de Safo. A partir de uma expressão confessa do homoerotismo feminino, buscar-se-á a compreensão do seu projeto literário, articulado nas criações efabulatórias de diferentes máscaras. Com isto, também pretende-se não só afirmar o seu nome no cenário do modernismo português, mas também apontar uma possível antecipação avant la lettre de algumas das principais reivindicações dos movimentos feministas contemporâneos.

PALAVRAS-CHAVE: homoerotismo feminino, máscaras poéticas, Judith Teixeira.

\begin{abstract}
This essay aims a reading proposal of Judith Teixeira's poetry, having as guiding bias her feminine writing under the sign of Sapho. From an expression of confessed female homoeroticism, it will seek the understanding of his literary project, articulated in fictional creations of different masks. With this, it also aims to not only to affirm his name in the Portuguese modernism scenario, but also to point out a possible anticipation avant la lettre of some of the main demands of the contemporary feminist movements.
\end{abstract}

KEYWORDS: female homoeroticism, poetry shades, Judith Teixeira. 
A burguesia, espavorida pelas labaredas da minha fantasia, anda de longe a apedrejar-me sem consciência porque só pode haver consciência nos cultos e nos iluminados; pois bem, que continue porque eu, numa leitura irreverente e sem remédio, hei-de continuar a dizer-lhe sinceramente, honestamente as minhas concepções de Arte no maior tom de verdade!

Judith Teixeira, De mim

A novidade, em tempos de manutenção de hábitos e tradições, sempre traz consigo um certo misto de surpresa, apreensão e (não necessariamente nesta ordem) escândalo. Quando se trata da percepção de movimentos intelectuais e artísticos, tal constatação é praticamente evidente, sobretudo quando se pensa nas diferentes correntes de vanguarda que povoaram o início do século XX, época de efervescência cultural e de renovações nos distintos campos das artes.

No que tange à literatura portuguesa das primeiras décadas novecentistas, esse cenário concretizou-se com a publicação da revista Orpheu, grupo composto por homens das mais diversas lavras - Fernando Pessoa, Mário de Sá-Carneiro, Alfredo Pedro Guisado, Luis de Montalvor e Armando Corte-Rodrigues, no drama e na poesia; Santa Rita Pintor e Amadeo de Sousa-Cardoso, na pintura; e Almada Negreiros, artista multímodo das letras e das artes plásticas, dentre outros -, responsável por injetar um frescor violento e, por vezes, agressivo, no meio da mesmice e da calmaria instituídas por um conservadorismo ainda permanente no cenário português do referido período.

Em sua instigante comparação entre as gerações de 1870 e de Orpheu, Cleonice Berardinelli chama a atenção para o impacto que esta repercutiu nos meios midiáticos de sua época. Para a ensaísta brasileira,

O impacto da nova literatura, causado principalmente pela Ode Triunfal de Álvaro de Campos e o poema 16 de Sá-Carneiro, é tremendo. Gritam os jornais de Lisboa e do Porto, chamando-lhe "Literatura de manicómio" e a seus poetas "doidos com juízo". Não contribuiria pouco para tal julgamento o aspecto de "blague", o desejo de "épater" de que o próprio Pessoa se penitenciaria logo depois. Mas não será esta uma das características dos movimentos de renovação, de inovação dirigidos por gente moça? Eça e Antero não inventaram poetas satânicos para ludibriar os leitores crédulos e não criaram o poeta Carlos Fradique Mendes? (BERARDINELLI, 1985, p. 168)

A par do impulso inovador que a nova geração de artistas imprimiu em 1915, em Portugal, entendemos que só a juventude não garantiria o sucesso e a consolidação dos nomes dos seus participantes no panteão da 
literatura portuguesa e do cenário artístico-cultural mundial. Vale destacar que as propostas "características dos movimentos de renovação" estão não apenas nos gestos e nos comportamentos, mas também, e sobretudo, nas obras que legaram como uma herança inconteste do modernismo português. Nesse sentido, o contexto epocal anunciado na afirmação de Cleonice Berardinelli vai ao encontro de todo um cenário prenhe de mudanças:

É fato que, de praxe, os modernistas se entusiasmavam mais com os extremos do que com o meio-termo político ou doutrinário. Apesar de todo o liberalismo de figuras centrais como James Joyce ou Henri Matisse, muitos modernistas achavam a moderação uma coisa burguesa e maçante - dois adjetivos que gostavam de tratar como sinônimos. [...] O único ponto incontestavelmente comum entre todos os modernistas era acreditarem que muito superior ao conhecido é o desconhecido, melhor do que o comum é o raro e que o experimental é mais atraente do que o rotineiro. Assim, a metáfora mais expressiva que podemos usar nessa busca de afinidades mais amplas é talvez a de uma grande família muito interessante e variada, com todas as suas expressões individuais diferentes, mas unida por alguns laços fundamentais, como necessariamente são as famílias. [...] Tal como um acorde, o modernismo foi mais do que um agregado fortuito de protestos de vanguarda; foi mais do que a soma de suas partes. Ele gerou uma nova maneira de ver a sociedade e o papel do artista dentro dela, criou uma nova forma de avaliar as obras culturais e seus valores. Em suma, o que chamo de estilo modernista foi um clima de idéias, sentimentos e opiniões. (GAY, 2009, p. 18-19)

O projeto poético de Fernando Pessoa, aquilo que acertadamente Teresa Cerdeira irá chamar de "aventura suicida da modernidade (CERDEIRA, 2000, p. 78), as investidas sensacionistas, interseccionistas e futuristas dos seus desdobramentos heteronímicos, as imagens decadentistas e simbolistas de Luis de Montalvor e Mário de Sá-Carneiro, além do satanismo de Almada Negreiros e a escrita vertígica de Raul Leal (ROCHA, 1985) constituem alguns dos passos desses extremos, são esses autores os membros daquela variada família modernista (portuguesa) de que fala Peter Gay. E se tais manifestações literárias contribuem para a composição desse "clima de idéias, sentimentos e opiniões" característico das primeiras décadas do século XX, em Portugal, há-de se destacar também que a reflexão ensaística marcou sua presença, recuperando nomes e aspectos estéticos sob uma nova perspectiva, além de se debruçar detidamente sobre aqueles que, na época, produziam e tentavam marcar seu território nesse cenário, em que a moderação não despertava interesse e o extremo e a exacerbação eram palavras-chave para o interesse da própria classe artística. Nesse sentido, um dos eventos mais marcantes nessa linhagem revolucionária de rasura do conformismo encontra-se no episódio conhecido como "Literatura de Sodoma". 
Depois de publicar o ensaio "António Botto e o ideal estético em Portugal", na revista Contemporânea (n. 3, julho-setembro de 1922), em que apontava a presença do autor de Canções como o mais genuíno poeta "a quem a designação de esteta se pode aplicar sem dissonância" (PESSOA, 1982, p. 348), Fernando Pessoa acaba por desencadear uma polêmica com Álvaro Maia (da Liga de Acção dos Estudantes de Lisboa) e Pedro Teotónio Pereira (da Federação Acadêmica de Lisboa), que duraria até 1923, ainda com o envolvimento de Raul Leal (com o seu artigo "António Botto e o sentido do ritmo" e, em sequência, a sua "Sodoma divinizada") e de Álvaro de Campos (com a publicação de "Aviso por causa da moral"). Contra o farisaísmo conservador de certa camada da sociedade portuguesa, Pessoa não deixou de reivindicar a visibilidade necessária a um poeta diferenciado não apenas pela temática de sua obra, mas sobretudo pela forma como a desenvolvia ao longo dos seus versos. E se esse ensaísmo pessoano já chamara a atenção para o poeta dos corpos olímpicos masculinos, José Régio, ao longo da publicação dos números da revista Presença, iria dar uma atenção especial ao autor de Curiosidades estéticas (1924), escrevendo uma série de ensaios, reunidos depois em António Botto e o amor (1978). Ou seja, tanto o poeta-ensaísta de Orpheu quanto o da geração posterior abriram espaço definitivamente para aquele exercício de criar "uma nova forma de avaliar as obras culturais e seus valores" (GAY, 2009, p. 19).

E, também, António Botto (e, não menos, Raul Leal), objeto dos ensaios acima referidos, artista assumidamente homossexual, não deixou de postular uma nova forma de pensar a beleza e o seu estatuto estético diante de normas ortodoxas e pouco condizentes com a sua maneira de ser e estar no mundo. Mas, se todos eles estiveram no centro das atenções dessa polêmica, interessa-me, aqui, recuperar um nome que, quase sempre, passa de forma despercebida nesse cenário de embates, discussões e opiniões exacerbadas e levadas ao extremo. Refiro-me a Judith Teixeira, escritora presente na mesma fogueira onde foram incluídos os nomes dos poetas acima mencionados.

Interessante destacar o quase total silenciamento dessa artista em tempos órficos, por parte da crítica - como se percebe na entrevista de Teotónio Pereira, por exemplo -, quando, no centro da celeuma, seu nome se destacava por se tratar da única mulher no meio de "certas publicações escandalosas que se não podem ter em casa e cujo título nem deve ser referido para se lhe não fazer reclamo" (apud LEAL, 1989, p. 93). Isto sem falar na desconfiança com que certos nomes significativos do pensamento crítico de sua época encaravam a sua obra. Nem mesmo no seu tempo, algumas mentalidades que reiteravam a singularidade poética de um António Botto, por exemplo, chegaram a ser complacentes com a sua produção literária. Basta lembrar, nesse sentido, as palavras pontuais de José Régio, no seu sempre retomado ensaio "Literatura viva", de 1927, quando postulava que "todos os livros de Judith Teixeira não valem uma canção escolhida de António Botto” (RÉGIO, 1977, p. 20). 
Uma das prováveis razões dessa desconfiança pode ser aventada por conta dos pressupostos criadores da geração da Presença, a que José Régio reconhecidamente pertencia, que versavam sobre o ato do artista, no momento da criação, em insuflar "a sua própria vida" (RÉGIO, 1977, p. 19) na matéria inventada. $\mathrm{Na}$ interessante releitura que faz do movimento presencista, Emerson da Cruz Inácio esclarece que:

[...] o texto "vivo" se coloca na medida em que, ao dar voz à intimidade e insuflar de vida o poema, mostra a capacidade de a vida ser vista e entendida também como uma manifestação artística, propiciando, assim, uma "cotidianização" da arte, bem aos moldes das proposições de vanguarda. Numa palavra: a experiência cotidiana torna-se, assim, motivo para a produção da poesia e razão de sua escrita; e o corpo, lugar em que primeiro se vive, ora é o próprio organismo biológico, ora é o local dentro do qual a própria poesia reside, ora aquilo que sustenta a sua existência, num processo metalingüístico constante em que corpo e escrita se confundem e se correspondem (INÁCIO, 2006, p. 18).

Ou seja, se se levar em conta que, por essa perspectiva, é possível perceber uma certa dissonância entre a vida e a obra da escritora portuguesa, faz-se necessário considerar com atenção não só a leitura da obra judithiana, mas também as considerações feitas pelo mestre presencista. Ainda que, conforme alenta René Garay, Judith Teixeira tenha sido uma "mulher inteligente e provavelmente amara 'saficamente' outras mulheres (em corpo e/ou espírito), o que era mais que suficiente para a sua condenação no contexto sexista, homofóbico e socialmente subdesenvolvido da vida europeia de princípios do século XX." (GARAY, 2002, p. 70), não se pode deixar de notar que, na sua trajetória biográfica, constam dois casamentos heterossexuais (com Jaime Levy Azancot, união dissolvida em virtude de acusações de adultério e abandono de lar por parte de Judith; e com Álvaro Vergílio de Franco Teixeira, de quem herda e passa a usar o ultimo sobrenome), o que poderia, num primeiro momento, ser entendido como uma das razões dos defensores da "literatura viva" não vislumbrar a ocorrência daquele fenômeno observado, em contrapartida, em outros poetas, como António Botto, por exemplo.

No entanto, acredito que, mais importante que tentar reiterar uma atitude lésbica nos comportamentos sociais da poetisa portuguesa em consonância com a sua obra literária, é procurar destacar a sua relevância enquanto escritora num cenário de intensa turbulência artística a que ela, aliás, não se furtou de participar e deixar a sua contribuição. Nas décadas iniciais do século XXI, quando muito se fala de visibilidade para os direitos dos homossexuais, lésbicas, transexuais e transgêneros, não se pode menosprezar que, há quase cem anos passados, uma mulher ousou nomear a multiplicidade do seu desejo e da sua subjetividade. Como, portanto, es- 
quecer ou delegar essa voz a um silenciamento, no mínimo, injusto? Nesse sentido, um olhar atento sobre a obra de Judith Teixeira, sobretudo quando se fala de literatura de autoria feminina, faz-se necessário e urgente.

Ainda que escritores do quilate de um Aquilino Ribeiro (1923), João Gaspar Simões (1937) e António Manuel Couto Viana (1977), por exemplo, tenham destacado aspectos relevantes na sua produção, seria apenas a partir dos anos 2000, com os reconhecidos trabalhos de René P. Garay (2000, 2002), Gouveia e Sousa (2002), Dal Farra (2007, 2010) e Silva e Vilela (2011), dentre alguns poucos, que a escritora começaria a sair, mesmo que de forma muito lenta e ainda não suficiente, do silêncio e da ignorância, cumprindo-se, assim, aquele vaticínio lançado por Couto Viana, em 1977.

Uma das evidências mais marcantes na poética judithiana encontra-se na livre verbalização de um desejo homo(lesbo)erótico, na feliz expressão de Fabio Mario da Silva e Ana Luísa Vilela (2011), dirigido a um objeto feminino, sem esconder a sua dicção feminina. Ou seja, sua escrita evidencia um homoerotismo feminino, ${ }^{2}$ encenando um desejo e uma afetividade lésbicos e marcando uma liberdade do sujeito lírico na construção de sua subjetividade singular, sobretudo se levado em conta o cenário em que tal efabulação poética se concretiza: o Portugal das décadas iniciais do século XX, recém saído de uma transição política delicada da monarquia para a república. Falar, portanto, de Judith Teixeira significa também adentrar pelo contexto do modernismo português, consolidado nos tempos de Orpheu, agora sob a ótica da criação de autoria feminina. Não será, por conseguinte, exagero considerá-la uma Safo em meio a uma Sodoma lusitana.

Nascida em $1880,{ }^{3}$ ou seja, dez anos antes do Ultimatum inglês, em Viseu, Judith Teixeira pertenceu a um tempo de mudanças drásticas e complexas, muitas vezes, pressentidas de forma violenta e arrebatadora. Num mundo essencialmente masculino, conservador e de ordem patriarcal, há-de se entender o porquê do incômodo de sua voz a pregar em alto e bom som uma disposição feminina liberta de quaisquer vínculos com este estatuto regulador dos comportamentos sociais e afetivos. Lida por esse viés, a sua obra não deixa de estabelecer pontos significativos de contato com aquela "primeira onda feminista" (BONNICI, 2007, p. 89), desencadeada nos final do século XIX e ao longo das primeiras décadas do século XX, na Inglaterra e nos Estados Unidos. A preocupação maior desse movimento, como bem esclarece Thomas Bonnici, foi a de estabelecer um vínculo de igualdade entre os direitos de homens e mulheres, além de analisar e combater "o dano psicológico e econômico feito às mulheres quando são forçosamente dependentes do sexo masculino e excluídas das responsabilidades públicas" (BONNICI, 2007, p.89).

Ainda que seja temerário incorporar o gesto de Judith Teixeira a essa linhagem, em que se vislumbram nomes como os de Josephine $\mathrm{Bu}$ tler (1828-1906), Barbara Leigh-Smith Bodichon (1827-1891) e Emmeline 
Pankurst (1858-1928), não me parece gratuito o fato de a escritora portuguesa ter sido diretora de um reconhecido periódico mensal da época (Europa, de 1925), com "secções diversas de cinema, desporto, teatro, moda, ficção científica e alguma colaboração literária (Américo Durão, Aquilino, etc.)" (ROCHA, 1985, p. 647), cujos temas, para além de superarem uma aparente veleidade de comportamentos femininos, não deixavam de sugerir muito mais uma participação ativa da mulher em assuntos que, até então, na sociedade portuguesa, eram de responsabilidade e exclusividade dos homens.

Nesse sentido, o olhar judithiano também não deixa de reivindicar o espaço feminino nas relações amorosas e no estabelecimento de laços afetivos, sem discriminar o objeto desejado e para onde se direcionam as atenções eróticas. Vale lembrar que não só ela, mas outra escritora também não deixou de passar por uma espécie de descrédito público, pelo simples fato de articular um discurso desejante marcado pela liberdade. Florbela Espanca, escritora deste cenário do entre séculos XIX-XX, com o seu "donjuanismo feminino" (RÉGIO, 1980, p. 179), como bem sublinhara José Régio, fincou definitivamente uma estaca no coração do estatuto regulador masculino ao declarar o livre trânsito da mulher nas sendas amorosas: "Eu quero amar, amar perdidamente! / Amar só por amar: Aqui... além... / Mais Este e Aquele, o Outro e toda a gente... / Amar! Amar! E não amar ninguém!" (ESPANCA, 1999, p. 232).

Ora, se essa dinâmica florbeliana afetou sobremaneira o status quo social e moralizante da época, como bem atesta Maria Lúcia Dal Farra (1999), não se pode esquecer que Judith Teixeira se inseriu de maneira sintomática nesse cenário, ao delinear um outro caminho possível, fora dos parâmetros controladores e patriarcais, porque, para além de reivindicar o seu grito de liberdade, consolidou também a possibilidade de dizer e efabular as múltiplas orientações do seu desejo. Talvez, por conta disso, René Garay a tenha associado a uma expressão sáfica, típica de um comportamento de rasura a certos modelos pré-concebidos por um conservadorismo ortodoxo, ainda presente nas primeiras décadas novecentistas em Portugal. Para o ensaísta, o uso da expressão "modernismo sáfico" (GARAY, 2002 , p. 37$)^{4}$ em relação ao processo criador de Judith Teixeira, cuja base encontra-se na produção da poetisa da ilha de Lesbos (Safo), abrange uma conotação ampla que, em sintonia com o modernismo de Orpheu, vem instaurar uma "técnica iconoclasta do discurso do género na modernidade” (GARAY, 2002, p. 69) portuguesa, afora a sua nítida conotação decadentista, outra evidência estética que a coloca em sintonia com as práticas artísticas de vanguarda:

Este processo estilístico do sáfico englobará, portanto, significados múltiplos que refletem uma nova estética do moderno. Para além de conotar a inversão sexual do sujeito ou de uma intertextualidade específica de motivos e estilos eólicos, o modernismo sáfico será um instrumento subversivo que privilegiará a sexua- 
lidade feminina. O sáfico torna-se, assim, um eros irreprimível, gerador também da criação poética. (GARAY, 2002, p. 69-70).

Logo, o dizer desejante de "corpos subtilizados, / femininos" (TEIXEIRA, 2002, p. 57) que se atraem num erotismo sáfico declarado não pode ser compreendido simplesmente como um desvio psicologizante de uma mente "desavergonhada" (CAETANO, 1926, p. 156), como queria uma certa crítica de sua época. Trata-se, na verdade, da expressão de uma subjetividade sensual/sexual que não perde jamais a consciência e o lastro de sua feminilidade, como bem se pode perceber nos versos de "Perfis decadentes":

Fitaram-se as bocas sensuais!

Os corpos subtilizados,

femininos,

entre mil cintilações

irreais

enlaçaram-se

nos braços longos e finos!

E morderam-se as bocas abrasadas,

em contorções de fúria, ensanguentadas!

Foi um beijo doloroso,

a estrebuchar agonias,

nevrótico, ansioso,

em estranhas epilepsias! (TEIXEIRA, 2002, p. 57)

É essa expressão de um desejo incontido, de bocas sensuais e sensualizadas pela pena poética, de beijos marcados por uma ansiedade nevrótica e por reações agônicas, como as "estranhas epilepsias", que faz da poesia de Judith Teixeira um marco na literatura portuguesa do início do século XX. Nesse poema, especificamente, é o sujeito lírico que, mesmo sem deixar marcas visíveis de seu gênero feminino, observa de maneira minuciosa "dois corpos esculpidos em marfim" (TEIXEIRA, 2002, p. 57) com seus "perfis esfíngicos,/ e cálidos" (TEIXEIRA, 2002, p. 57). Mesmo, portanto, não estando diretamente envolvida com a ação descrita, a voz poética não deixa de perceber e efabular a cena do encontro entre estes dois entes consumidos pela paixão. Ora, não seria, assim, uma maneira outra de participar do ménage, valendo-se de uma postura de voyeur, de alguém que se compraz na observação atenta do prazer dividido entre as partes agentes do enlace físico? Não seria esse voyeurismo poético uma forma de também ser parte integrante de um jogo erótico sáfico, até porque o observar e o descrever não eliminam a sua participação? Gosto de pensar, nesse sentido, que essa postura supostamente passiva, de quem não estaria inserida na própria cena criada, trata-se de uma máscara possível por onde o safismo judithiano se espraia. 
Em outro poema, num gesto assumido de participação entre dois seres, explícita ou metaforicamente femininos, como acontece, por exemplo, em "Rosas vermelhas", o sujeito lírico declara, sem o menor pudor ou restrição, a sua "estranha fantasia" (TEIXEIRA, 2002, p. 75):

\section{Comprei rosas encarnadas}

às molhadas

Dum vermelho estridente,

Tão rubras como a febre que eu trazia...

- E vim deitá-las contente

Na minha cama vazia!

Toda a noite me piquei

Nos seus agudos espinhos!

E toda a noite beijei

Em deslinhos... (TEIXEIRA, 2002, p. 75).

É certo que, ao contrário do poema anterior, neste, a voz poética assume-se como participante num jogo erótico com imagens metaforicamente femininas ("rosas encarnadas/ às molhadas/ dum vermelho estridente"), e no plural, conotando não apenas uma participação em dupla, mas em multiplicidade de agentes. Afinal, na cena poética, as "rosas encarnadas", vermelhas, também não tomam parte na fantasia do eu lírico? E não são elas o símbolo do feminino, da regeneração e do amor, dedicadas à Afrodite (CHEVALIER; GHEERBRANT, 1991, p. 788-789)? Vale lembrar, aqui, que, de maneira muito semelhante ao relato mítico de transformação da cor da flor, de branca para vermelha, ${ }^{5}$ no poema, também o eu poemático performatiza o seu ensanguentamento, sugerindo não uma mudança de tonalidade, mas uma perfeita integração entre sujeito amante e objeto desejado:

Toda a noite me piquei nos seus agudos espinhos!

E toda a noite beijei em desalinhos...

A janela toda aberta meu quarto encheu de luar...

- Na roupa branca de linho, as rosas, são corações a sangrar... (TEIXIRA, 2002, p. 75)

Ou seja, colocadas as duas situações lado a lado, a de voyeur e a de amante assumida, elas não diminuem a carga de eroticidade que tanto uma quanto a outra desnuda ao leitor, ao contrário, ambas contribuem para a construção de máscaras sucessivas por onde o sujeito feminino deixa extravasar a sua subjetividade.

A escrita de Judith Teixeira parece, assim, dialogar intertextualmente com a sensualidade sáfica da poetisa grega clássica. Dela, consegue 
captar as principais referências criadoras e redimensiona-as no seu universo artístico do início do século XX, deixando rastros inconfundíveis de uma artista contextualizada no cenário das vanguardas e da modernidade crescente nos primeiros decênios novecentistas. É Marguerite Yourcenar quem chama a atenção para a singularidade de Safo, na Antologia de poesia grega clássica, em tradução de Albano Martins:

A expressão do amor é, em todo o caso, em Safo, duma delicadeza que se desejaria poder dizer especificamente feminina. Feminina, também, a confissão agitada do ciúme, tanto profissional como amoroso, nesse pequeno mundo de amigas e de músicas. Feminino, um sentido quase convencional das conveniências, que lhe faz desprezar uma mulher que se veste mal e repreender o irmão arruinado "pela cadela duma cortesã". Feminino, mas sobretudo jônico, o gosto dos perfumes, dos unguentos, a paixão dos vestidos bonitos, quase igual à dos corpos belos, e a languidez voluptuosa dos poemas de amor, muito próxima da que sempre impregnou as melopeias da Ásia Menor. Quanto ao delicado sentido das flores, dos belos aspectos do mar, do céu nocturno e da natureza primaveril, ele é comum a todos os poetas do seu século. Safo ultrapassa-os mesmo pela amplitude das suas comparações, que fazem pensar na do Salmista, contemporâneo, afinal, desta civilização da Jónia. Assim a evocação dum exército em linha de batalha e duma esquadra ao ar livre para descrever a beleza de Anactória. A arte de Safo nada tem de enfadonho, de frouxo ou de artificial (in ANTOLOGIA, 2009, p. 114).

Destarte, em Safo, é perceptível uma amplitude da sensibilidade feminina, que abrange a confissão marcada pelo ciúme, o discurso que aproxima e afasta elementos masculinos e femininos, o gosto por objetos estéticos, que vão desde os perfumes às vestimentas, e a representação de cenários naturais. Na escritora de Lesbos, a variedade de imagens e máscaras poéticas presentes na sua realização constitui uma realidade marcante. E se, nela, tal dinâmica ultrapassa a prática comum do seu tempo, não menos em Judith Teixeira essa variedade de composições deixa de transparecer. É preciso sublinhar, porém, que a recuperação sáfica operada na articulação lírica da autora de Decadência realiza-se a partir da criação de máscaras sucessivas que se vão acrescentando, umas sobre as outras, e com as quais vai sutilmente tecendo as múltiplas subjetividades femininas que a sua verve comporta.

Às de voyeur e de amante ativa, soma-se a faceta de uma narcísica observadora de si própria, que se apaixona pelo que vê, porque na imagem refletida no espelho absorve traços estéticos de uma beleza invulgar. As cores, os encantos e as formas seduzem o sujeito lírico feminino, a ponto de ele próprio não conseguir conter o ímpeto erótico, como se pode perceber nos versos de "Ao espelho": 
As horas vão adormecendo

preguiçosamente...

$\mathrm{E}$ as minhas mãos estilizadas,

vão desprendendo

distraídamente,

as minhas tranças doiradas.

Reflectido no espelho

que me prende o olhar,

desmaia o oiro vermelho

dos meus cabelos desmanchados,

molhados

de luar!

Suavemente, as mãos na seda,

Vão soltando o leve manto...

Meu lindo corpo de Leda,

fascina-me, enamorada

de todo o meu próprio encanto...

Envolve-se a lua

em dobras de veludo

nos páramos do céu

e eu vou pensando,

no cisne branco e mudo

que no espelhante lago adormeceu...

Volta o luar silente...

E a minha boca ardente

numa ansiedade louca

procura ir beijar

o seio branco e erguido,

que no cristal do espelho ficou reflectido!...

Impossíveis desejos!

Os meus magoados beijos

encontram sempre a própria boca

banhada de luar

álgido e frio -

Dizendo em segredo

às minhas ambições,

o destino sombrio

das grandes ilusões! (TEIXEIRA, p. 83-85)

Diante do penteado que se desfaz pela atuação das mãos e do seu reflexo na tela do espelho, o olhar do sujeito poético magnetiza-se diante do objeto revelador da beleza, daí que o primeiro impacto da visão dos "cabelos desmanchados" acaba por incitar a exposição liberta de outra ma- 
téria estética: o próprio corpo revelado na sua pujança, diante das mesmas "mãos de seda" que "vão soltando o leve manto". Este constitui a substância de maior incidência para onde convergem os desejos eróticos: "Meu lindo corpo de Leda,/ fascina-me, enamorada/ de todo o meu próprio encanto...." Não deixa de se configurar, portanto, tal como aquele "donjuanismo feminino" (RÉGIO, 1980, p. 179), numa multiplicidade de enamoramento que não exclui nem o reflexo do corpo e nem o objeto refletido: "E a minha boca ardente/ numa ansiedade louca/ procura ir beijar/ o seio branco e erguido,/ que no cristal do espelho ficou refletido!...” Tão narcísica e sáfica é essa máscara judithiana que, em “Os meus cabelos”, ela será retomada para, novamente, reiterar uma autoeroticidade feminina. Apaixonada pela visão contemplada, a voz poética exacerba o seu desejo:

\author{
Doirado, fulvo, desmaiado \\ e vermelho, \\ tem reflexos de fogo o meu cabelo! \\ Neste conjunto diverso, \\ quando me vejo assim, ao espelho, \\ encontro no meu todo, um ar perverso...
}

Gosto dos meus cabelos tão doirados!

E enterro com volúpia,

os dedos esguios,

por entre os meus fios

d'oiro, desgrenhados,

revoltos e macios! (TEIXEIRA, 2002, p. 43).

Fico a interrogar se, a par da distância que separa a sua obra das questões levantadas pela "segunda onda feminista" (BONNICI, 2007, p. 101) - de onde sairia, aliás, a insatisfação dos rumos tomados pelo movimento reivindicador dos direitos da mulher e, por conseguinte, o "feminismo lésbico" (BONNICI, 2007, p. 101) nas décadas de 1960 e 1970- , as imagens e os eixos temáticos da produção de Judith Teixeira já não estariam apontando para um caminho irreversível de antinormativização dos comportamentos femininos, oferecendo uma possibilidade outra de manifestação da subjetividade erótico-sensual dos seus agentes? Afinal, não será ela a, por mais de uma vez, proclamar a sua atitude avant garde: "Noutros cenários a minha alma vive!/ Outros caminhos.../ Por outras luzes iluminada!/ - Eu vim daquele mundo onde estive,/ tanto tempo emparedada..." (TEIXEIRA, 2002, p. 89)? É claro que afirmar categoricamente a ligação entre a escritora portuguesa e as agitações políticas das ondas feministas, decorrentes ao longo do século XX, seria por demais temerário; no entanto, não se pode negar que Judith Teixeira explicita todo um inconformismo, típico dos artistas dos modernismos e das vanguardas, em "querer investir contra o conservadorismo" e "escandalizar o burguês pacato" (BERARDINELLI, 1985, p. 167), não apenas a colocando, assim, em consonância com 
os homens da geração órfica, mas também conferindo à sua voz uma reivindicação avant la lettre do papel delegado ao sujeito feminino.

As máscaras sáficas bem apontam esse caminho de leitura, no entanto, a sua escrita apresenta-se de maneira tão rica e variada, que, para além destas, outras também podem ser observadas, como aquela em que a voz da mulher autentica uma relação incomum (e, para não dizer, até mesmo exótica, levando em consideração o objeto eleito para a sua realização) com um outro, fora dos parâmetros estéticos da beleza europeia e portuguesa, tal como ocorre em "O meu chinês":

Nos olhos de seda

traçados em viés,

tem um ar tão sensual

o meu Chinês...

Vive sobre uma almofada

de cetim bordada,

pintado a cores.

Às vezes

numa ânsia inquieta

que eu não mitigo,

e que me domina,

num sonho de poeta

ou de heroína,

fujo levando

o meu Chinês comigo!

E lá vamos!

Nem eu sei

para que alcovas orientais,

em que países distantes,

realizar

as horas sensuais,

as horas delirantes

com que eu sonhei...

Eu e o meu Chinês

temos fugido tanta, tanta vez! (TEIXEIRA, 2002, p. 41).

Ao contrário dos outros poemas aqui resgatados, neste, o alvo dos sonhos e dos anseios da voz poética não é um objeto feminino, mas masculino e completamente diferente do estereótipo esperado. Isto não quer dizer, porém, que a atenção do eu lírico não seja capaz de captar a atração que o chinês desperta no seu imaginário. É através da "ânsia inquieta” e do "sonho de poeta" que sujeito desejante e objeto desejado estabelecem uma 
simbiose plena, capaz de os arrebatar para um espaço-tempo onde o exercício da liberdade amorosa seja a única tônica possível:
E lá vamos!
Nem eu sei
para que alcovas orientais,
em que países distantes,
realizar
as horas sensuais,
as horas delirantes
com que eu sonhei...

Não será de estranhar, portanto, que, independentemente do outro com quem definitivamente se envolve, a liberdade de escolha, o sonho sensualizado e a movimentação desimpedida forneçam os instrumentos possíveis para a expressão de uma eroticidade desligada de qualquer vínculo controlador. Até que ponto esses "países distantes" para realizar as "horas delirantes" não poderão ser lidos como uma espécie de "Pasárgada" para o eu-lírico? Ainda que, em "O meu chinês", este não seja "amigo do rei” (BANDEIRA, 1970, p. 127), como prevê o conhecido poema modernista de Manuel Bandeira, certamente, é para onde os dois (o sujeito poético feminino e o amante chinês) convergem num trânsito fluido e dinâmico, sem qualquer preocupação de controle externo às suas ações: "Eu e o meu Chinês/ temos fugido tanta, tanta vez!”.

Percebe-se, portanto, que a poética de Judith Teixeira, mesmo deixando flagrante uma pulsão sáfica, dirigida a um objeto feminino sem abrir mão da livre expressão verbal do agente também no feminino, não essencializa uma hierarquização deste sobre o objeto masculino, quando este desperta a atenção e o olhar desejantes. Nesse sentido, acredito que essa seja mais uma das máscaras criadas por Judith Teixeira para dar vazão à sua livre amorosidade. Em fazendo essa articulação, é sensível a forma como a poetisa estabelece contatos dialogantes com toda uma contemporaneidade sua, afinal, não estará ela também ecoando aquele "Eu quero amar, amar perdidamente!” (ESPANCA, 1999, p. 232), proclamado por Florbela Espanca, anos mais tarde, em Charneca em flor? Não será essa mais uma máscara de Judith Teixeira com a finalidade de dispor uma certa “imagem literária do fingimento" (ROCHA, 1985, p. 324), tão típica das recorrências estéticas das primeiras décadas do século XX? Não estará o gesto da escritora muito próximo daquela deposição do recurso ficcional performatizado por um Álvaro de Campos, por exemplo: “Depus a máscara e vi-me ao espelho..." (PESSOA, 2012, p. 209)?

Vale sublinhar que esse poema não é um caso isolado na produção judithiana. A personagem Maria de Jesus, mãe de Maria da Luz, do conto "Almas simples (Fé)", vive a esperança de rever António, seu amado e pai da menina, que parte para a França seis meses depois do seu casamen- 
to. Ao receber de lá a notícia do seu suposto falecimento, visto que já não recebia qualquer carta ou notícia, num desespero assumido, a mulher põe-se numa romaria cotidiana para rezar à Virgem, até que, um dia, percebe que suas preces foram atendidas e António, seu único e verdadeiro amor, retorna. Porém, diante do processo agônico a que se viu submetida, ela não resiste ao reencontro e acaba por morrer de felicidade.

Ora, a partir dessa breve síntese da trama ficcional, é interessante observar que, como no poema "O meu chinês", a personagem feminina de "Almas simples", ainda que sucumbida pela morte, também é descrita sob o signo da liberdade, do livre arbítrio, da escolha própria sobre o seu destino: "Dera-lhe Deus a fé e a crença que amparam as almas puras na desgraça; mas o seu pobre coração tão ferido e maguado, não poderá resistir a felicidade!... A sua alma ingenua e dôce partira para o Céu." (TEIXEIRA apud GARAY, 2002, p. 211).

Como afirmado anteriormente, essas construções não me parecem gratuitas, visto que deliberam um sujeito feminino ansioso pela expressão de uma verve de criação liberta de quaisquer instrumentos reguladores. Não será por acaso que o sintomático poema "Última frase", que encerra Decadência, confirmará essa ânsia de liberdade, ao retomar as conhecidas imagens e suas redes semânticas que reiteram este ímpeto de ir para além de: "Minha alma ergueu-se para além de ti.../ Tive a ânsia de mais alto/ - abri as asas, parti!" (TEIXEIRA, 2002, p. 119). Ou seja, mais importante que descrever ou delinear o outro a quem se refere como alvo a ser atingido e ultrapassado, é a necessidade do eu lírico de reafirmar o gesto autônomo de erigir o seu caminho, de vislumbrar o ponto de chegada almejado e, por fim, de tomar a iniciativa de conquistar a própria liberdade.

Seja, portanto, pelas máscaras da voyeur, da amante, seja pela da narcísica contempladora, ou, ainda, da mulher que não faz distinção entre os seus objetos desejados, Judith Teixeira confirma o seu modernismo sáfico em tempos de Orpheu. A sua escrita feminina reivindica um espaço de significação e relevância, sem abrir mão da criação literária como manifestação singular de autonomia e liberdade. E, nessa perspectiva, alinha-se também com toda uma tradição poética portuguesa, na medida em que consuma à sua maneira a máxima camoniana, afinal, também não será pela "virtude do [seu] muito imaginar" que o amador deliberadamente se transforma na "cousa amada" (CAMÕES, 1988, p. 90)? Confirma-se, portanto, a minha proposta de ler a obra poética de Judith Teixeira, nas suas articulações efabulatórias em máscaras que se desdobram e se acrescentam, como um tecido esteticamente refinado e contextualizado no cenário das décadas iniciais do século XX, sem abdicar das "suas concepções de Arte no maior tom de verdade" (TEIXEIRA, 1996, p. 217). Apesar do apedrejamento público a que foi exposta, a sua obra permanece, ainda, como um marco inconteste da afirmação feminina na sua diversidade. Foi, nesse sentido, realmente, uma Safo numa Sodoma portuguesa em tempos de Orpheu. 


\section{REFERÊNCIAS BIBLIOGRÁFICAS}

ANTOLOGIA da poesia grega clássica. Tradução e notas complementares de Albano Martins. Lisboa: Portugália, 2009.

BANDEIRA, Manuel. Estrela da vida inteira. Rio de Janeiro: José Olympio, 1970.

BERARDINELLI, Cleonice. Estudos de literatura portuguesa. Lisboa: Imprensa Nacional - Casa da Moeda, 1985.

BONNICI, Thomas. Teoria e crítica literária feminista. Conceitos e tendências. Maringá: EdUEM, 2007.

CAETANO, Marcello. "Arte" sem nenhuma moral. Ordem nova, Lisboa, no. 4-5, p. 156-157, junho-julho de 1926.

CALINESCU, Matei. As cinco faces da modernidade. Trad.: Jorge Teles de Menezes. Lisboa: Vega, 2000.

CAMÕES, Luis de. Poesia lírica. Lisboa: Ulisséia, 1988.

CERDEIRA, Teresa Cristina. O avesso do bordado. Lisboa: Caminho, 2000.

CHEVALIER, Jean; GHEERBRANT, Alain. Dicionário de símbolos. 4. ed. Trad.: Vera da Costa e Silva, Raul de Sá Barbosa, Angela Melim e Lúcia Melim. Rio de Janeiro: José Olympio Editora, 1991.

COSTA, Jurandir Freire. A inocência e o vício. Estudos sobre o homoerotismo. Rio de Janeiro: Relume Dumará, 2002.

DAL FARRA, Maria Lúcia. Florbela: um caso feminino e poético. In: ESPANCA, Florbela. Poemas. Estudo introdutório, organização e notas de Maria Lúcia Dal Farra. São Paulo: Martins Fontes, 1999, p. v-xliv.

. Gilka Machado e Judith Teixeira: o maldito no feminino. Boletim, Araraquara: UNESP/Centro de Estudos Portugueses Jorge de Sena, ano XV, n. 25, p. 157-186, jan./dez. 2007.

. Judith Teixeira. In: MARTINS, Fernando Cabral (coord.).

Dicionário de Fernando Pessoa e do Modernismo português. São Paulo: Leya, 2010, p. 845-846.

ESPANCA, Florbela. Poemas. Estudo introdutório, organização e notas de Maria Lúcia Dal Farra. São Paulo: Martins Fontes, 1999.

GARAY, René P. Alguém se recorda deste nome: Judith Teixeira? Artes \& Artes, Lisboa, no. 29 (setembro/outubro de 2000).

. Judith Teixeira: o modernismo sáfico português. Lisboa: Universitária Editora, 2002. 
GAY, Peter. Modernismo: o fascínio da heresia. De Baudelaire a Beckett e mais um pouco. Trad.: Denise Bottmann. São Paulo: Companhia das Letras, 2009.

GOUVEIA E SOUSA, Martim de. Decadência, o primeiro livro de Judith Teixeira. In: TEIXEIRA, Judith. Decadência. Viseu: Instituto Politécnico de Viseu, 2002, p. 3-28.

INÁCIO, Emerson da Cruz. A herança invisível: ecos da "literatura viva" na poesia de Al Berto. Tese (Doutorado em Letras Vernáculas, Literatura Portuguesa). Rio de Janeiro: Faculdade de Letras da UFRJ, 2006.

LEAL, Raul. Sodoma divinizada. Organização, introdução e cronologia de Aníbal Fernandes. Lisboa: Hiena, 1989.

LISBOA, Eugénio. Dicionário cronológico de autores portugueses. Lisboa: Europa-América, 1994.

PEREIRA, José Carlos Seabra. História crítica da literatura portuguesa [Do fim-de-século ao Modernismo]. Lisboa: Verbo, 1995.

PESSOA, Fernando. Antologia poética. Organização, apresentação e ensaios de Cleonice Berardinelli. Rio de Janeiro: Casa da Palavra, 2012. Obra em prosa. Rio de Janeiro: Nova Aguilar, 1982.

RÉGIO, José. Ensaios de interpretação crítica. 2. ed. Lisboa: Brasília Editora, 1980. Editora, 1977.

. Páginas de doutrina e crítica da "presença". Lisboa: Brasília

RIBEIRO, Aquilino. A moral no teatro. Diário de Lisboa. Lisboa, p. 4, 20 de julho de 1923.

ROCHA, Clara. Revistas literárias do século XX em Portugal. Lisboa: Imprensa Nacional - Casa da Moeda, 1985.

SILVA, Fábio Mario da; VILELA, Ana Luísa. Homo(lesbo)erotismo e literatura, no Ocidente e em Portugal: Safo e Judith Teixeira. In: Navegações. Porto Alegre: PUC-RS, vol. 4, no. 1, p. 69-76, jan./jun. 2011. Disponível em: http://revistaseletronicas.pucrs.br/ojs/index.php/navegacoes/article/viewFile/9442/6542. Acesso em 25 de novembro de 2012.

SIMÕES, João Gaspar. Os livros da semana. Suplemento literário do Diário de Lisboa. Lisboa, p. 4, 29 de janeiro de 1937.

TEIXEIRA, Judith. Almas simples (Fé). In: GARAY, René P. Judith Teixeira: o modernismo sáfico português. Lisboa: Universitária Editora, 2002, p. 209-211.

. Decadência. Viseu: Instituto Politécnico de Viseu, 2002. 
De mim. Edição de Maria Jorge e Luis Manuel Gaspar. Lisboa: Edições culturais do subterrâneo, 1996.

VIANA, António Manuel Couto. Coração arquivista. Lisboa: Verbo, 1977.

Recebido para publicação em 02/11/2012

Aprovado em 15/02/2013

\section{NOTAS}

1 Este trabalho foi realizado no âmbito de Pós-Doutorado Sênior - CAPES 10171/12-6, na Universidade do Porto.

2 Emprego o termo "homoerótico", em consonância com o conceito defendido por Jurandir Freire Costa, que define o "homoerotismo" como "a possibilidade que têm certos sujeitos de sentir diversos tipos de atração erótica ou se relacionar fisicamente de diversas maneiras com outros do mesmo sexo biológico" (COSTA, 2002, p. 22), ou seja, a expressão pode ser entendida como "uma possibilidade a mais que têm os indivíduos de se realizar afetiva e sexualmente" (COSTA, 2002, p. 73). Em virtude de, muitas vezes, o termo ser entendido exclusivamente como dirigido a um sujeito masculino, Fabio Mário da Silva e Ana Luisa Vilela (2011) optam pela derivação de "homo(lesbo)erotismo" a fim de evitar quaisquer dúvidas em relação ao objeto tratado: o amor e o desejo sentidos e representados por e entre mulheres.

3 Durante algum tempo, a data de nascimento da escritora ficou sob o signo da dúvida. No Dicionário cronológico de autores portugueses, sob a coordenação de Eugénio Lisboa (1994), aparece o ano de 1873. No entanto, em 1996, na edição dos Poemas da autora, realizada por Maria Jorge e Luis Manuel Gaspar, a suspeita é definitivamente desfeita, com a utilização de documentos comprobatórios do ano exato do nascimento de Judith Teixeira: 1880. Posteriormente, outros estudiosos de sua obra (GARAY, 2002; DAL FARRA, 2010) seguirão esta linha biográfica. Centrada toda ela na década de 1920, a sua obra publicada compreende livros de poemas: Decadência (1923), Castelo de sombras (1923), Nua. Poemas de Bizâncio (1926); uma conferência: De mim (1926); e de ficção: Satânia. Novelas (1927).

4 Em outro momento, René Garay postula a singularidade da autora de Decadência: “O mérito fundamental de Judith Teixeira reside na sua originalidade, ao procurar captar a realidade em novos modos de expressão. A sua poesia está ligada à arte decadentista, pelo seu poder de sedução, ambiguidade, dor, alegria, sonho, utopia, misticismo e religiosidade, morte e vida. A sua visão gerava, por vezes, a indefinição semântica ou modal. No entanto a sua apreensão aguda das coisas e a confissão do prazer dos sentidos, potenciava momentos únicos de afirmação e de projecção de uma realidade sem preconceitos e de uma consciência ímpar" (GARAY, 2002, p. 22-23). Apesar do viés de leitura aqui proposto não incidir sobre a questão do lastro decadentista na poesia de Judith Teixeira - cf., neste caso, o minucioso ensaio de René Garay (2002) -, não se pode negar que esse traço reivindica uma consolidação da modernidade poética (PEREIRA, 1995; CALINESCU, 2000) em muitos outros escritores do início do século XX em Portugal, como Luís de Montalvor, Mário de Sá-Carneiro e Fernando Pessoa, por exemplo.

5 No Dicionário de símbolos, Chevalier e Gheerbrant esclarecem como se deu essa mudança de tonalidade na flor. Segundo os pesquisadores, "a rosa era entre os gregos uma flor branca, mas, quando Adônis, protegido de Afrodite, foi ferido de morte, a deusa correu para socorrê-lo, se picou num espinho, e o sangue coloriu as rosas que lhe eram consagradas" (CHEVALIER; GHEERBRANT, 1991, p. 789). 